\title{
EFFECT OF SPROUTED GREEN FODDER ON GROWING LAMBS' PERFORMANCE
}

\author{
K. K. Hegab ${ }^{1}$ and A.E.M. Mahmoud ${ }^{2}$ \\ ${ }^{1}$ Agriculture Engineering Dept., Faculty of Agriculture, Cairo University,12613, Giza, Egypt. \\ ${ }^{2}$ Animal Production Department, Faculty of Agriculture, Cairo University, 12613, Giza, Egypt.
}

\author{
(Received 6/6/2019, accepted 22/7/2019)
}

\section{SUMMARY}

$\mathrm{T}$ wenty-eight Rahmani lambs were used in growth trial to examine effect of sprouted barley grain in sheep ration. Trials lasted to 90 days to investigate growth performance, digestion coefficients, rumen and blood parameters. Animals in control ration $(\mathrm{G} 1)$ were fed clover hay $(\mathrm{CH})$ plus concentrate feed mixture (CFM) (30 CH:70 CFM), where animals in in G2, G3 and G4 were fed 20\%, 40\% and 60\% from dry matter intake green barley, respectively plus clover hay and CFM. Results indicated that G4 recorded higher significant digestibility of crude protein, ether extract, neutral detergent fiber and hemi-cellulose followed by G3, $\mathrm{G} 2$ and G1, respectively. Ruminal $\mathrm{pH}$ values were significantly higher with G1 compared with other groups at 4 hours and overall mean values. No significant differences were recorded in TVFA's concentration among all groups in all sampling times. Groups fed rations contained green barley recorded higher values of average daily gain by $15 \%, 27 \%$ and $31 \%$ with G2, G3 and G4 respectively compared with control. Generally, there were positive effects on performance of growing lambs fed on sprouted grains.

Keywords: Sprouted barley, lambs, growth, and digestibility.

\section{INTRODUCTION}

Green feeds are considering an economic and vital source to supplying livestock by the nutritional elements. Food insecurity exists when people do not have adequate physical, social, or economic access to food (FAO 1996, and FAO 2002). In the same time there is a huge problem in water availability reached to scarcity. Given the above points, researchers are trying to find new ways to solve this dilemma. One of ways is using hydroponic technique in green fodder production or produce sprouted grains to use in livestock feeding.

Hydroponic green fodder is the method to produce forage through germination of grains and it grown for short period of time in condition providing suitable growing requirements (Sneath and McIntosh, 2003). In another context, Khattak et al. (2007) said that sprouting is a simple way to germinate the seeds to enhance its feeding values. Also, sprouted green forage could be produced from cereals and legumes seed; however, barley grains became common in this way because of its price and availability around the world.

Studies related to using sprouted green barley in animal feeding observed that, crude protein content in the fresh matter around 16 to $17 \%$. Digestibility was more $85 \%$ in in vitro study. Using sprouted barley in the diet of growing lambs and ewes improved the performance (Intissar and Eshtayeh, 2004 and Fayed, 2011). Al-Saadi (2016) noticed that feeding Awassi lambs in 10 and 30\% of sprouted barley from all diet, total dry matter intake and total body weight gain were increased, feed conversion efficiency and economical profit particularly in 30\% decreased. In the same trend, Ata (2016) showed that hydroponic barley had a positive effect on performance of growing Awassi lambs when it fed on barley as green fodder up to $62 \%$ from its diet.

Despite these numerous benefits of sprouted green fodder and condition of each country, this point still need more studies to verify that it can be used to replace part of a whole diet not only green fodder needed. So, this study aimed to investigate using of sprouted green barley in growing lamb diet on growth performance, digestibility, rumen and blood parameters. 


\section{Hegab and Mahmoud}

\section{MATERIALS AND METHODS}

\section{Grain fodder production:}

The green fodder production trails of the soilless sprouted barley were executed inside the hydroponics green fodder chamber located in Agric. Eng. Dept., Cairo University. The chamber air temperature and lighting time were automatically controlled using electric control system. Production was divided to be fresh every day by three growth periods( 8,9 and 10 days). Fresh batches of green fodder were weighed and sampled to estimate dry matter and another chemical analysis.

Animals: Twenty-eight Rahmani lambs with an average body weight (BW) of $29 \mathrm{~kg}$ and 4 months of age were divided into 4 groups (7 each) according to BW in growth trial for 90 days. All animals were initially weighed, treated for elimination of internal parasites.

Rations and feeding procedures: Diet for control group contained $70 \%$ concentrate feed mixture (CFM) and $30 \%$ clover hay. The G2 was fed sprouted green barley (SGB) to replace $20 \%$ from dry matter intake (DMI) of CFM and clover hay; G3) was fed SGF to replace $40 \%$ of DMI plus CFM and clover hay and G4) was fed SGF to replace $60 \%$ of DMI plus CFM and clover hay. Diets were supplied according to NRC (1985) to growing lambs (in groups) in the morning at 8:00 am, and in the afternoon at 5:00 pm. Water was allowed freely all-day round. Daily feed intake was recorded for each group and each animal inside groups was weighed every 15 days to calculate daily body weight gain. The dry matter intake was adjusted after weighing according to body weight changes.

Digestion trials: Three animals from each group were used to evaluate digestibility and nutritive values of the experimental diets. So, metabolic cages were used to determine total amount of feces from each animal during seven consecutive days after growth trial ended. Animals through this period were fed individually to cover maintenance allowance according to NRC (1985). Feces were collected daily, and samples were combined (on a wet basis) to form a composite sample. Samples were dried at $60{ }^{\circ} \mathrm{C}$ in a forced-air oven for 3 days and ground in a knives mill to pass through a $1 \mathrm{~mm}$ screen (Wiley Mill, A. H. Thomas, Philadelphia, PA, USA).

Chemical analysis: Samples of feed and feces were analyzed for DM (method 934.01), ash (no. 942.05), crude protein (no. 968.06), crude fiber (A.O.A.C. no. 942.05) and crude fat (EE, ether extract) (no. 942.05) according to A.O.A.C. (1990). The organic matter (OM) was calculated as the difference between DM and ash contents. Also, nitrogen free extract was calculated by differences according to the following equation $(\mathrm{NFE}=100-(\%$ secondary moisture $+\%$ ash $+\% \mathrm{CP}+\% \mathrm{EE}+\% \mathrm{CF})$. Neutral detergent fiber (NDF), acid detergent fiber (ADF) and acid detergent lignin (ADL) excluding residual ash were determined according to the methods of Van Soest et al., (1991). The cellulose and hemicelluloses were calculated by difference, where, cellulose $=\mathrm{ADF}-\mathrm{ADL}$ and hemicelluloses $=$ NDF-ADF.

Rumen liquor sampling and analysis: On day 8 in collection sample period, ruminal fluid samples (200 mL) were collected by stomach tube before the morning feeding ( $0 \mathrm{hrs}$.) and $4 \mathrm{hrs}$. after the morning feeding straining rumen digesta (collected from all rumen sites) in four layers of cheese cloth (Vendramini et al., 2016). Ruminal $\mathrm{pH}$ was measured directly after each sample using a Beckman $\mathrm{pH}$ meters. Ammonia $\left(\mathrm{NH}_{3^{-}}\right.$ N) was determined according to Preston (1995). Total volatile fatty acids (VFA's) estimated by steam distillation method according to AOAC (Cunniff, 1997).

Blood samples and parameters: After four hours post morning feeding blood samples were withdrawn from all the experimental animals. The blood samples were taken from jugular vein into dry clean glass tubes using heparin as anticoagulant and then centrifuged for 15 minutes at $3000 \mathrm{rpm}$ to obtain plasma. Total protein and creatinine were determined according to Tietz (1986 and 1990), albumin was described by Doumas et al. (1971), blood was urea determined according to Patton and Grouch (1977). Alanin amino transfers (ALT) and activity of aspartate transfers (AST) were determined by the methods of Young (1997). Blood analysis was conducted using Mini Screen spectrophotometer (Germany) and using kits purchased from biodigenostic Co. (Egypt).

Statistical analysis: All results were conducted using the SAS package (SAS, 2001). The statistical model was: $Y_{i j}=\mu+G_{i}+e_{i j}$, where $Y_{i j}=$ observation of the effect of treatment $G$, the animal $\mathrm{i}, \mu=$ overall mean and $\mathrm{e}_{\mathrm{ij}}=$ random error associated with each observation. Means differences among treatment were separated according to Duncan's New Multiple Range Test (Duncan, 1955). 


\section{RESULTS AND DISCUSSION}

\section{Chemical composition of the experimental feeds and rations:}

Data of chemical composition and fiber fractions content in feedstuffs and the experimental rations of growing lambs are shown in Table (1). Results indicated that sprouted green barley was higher in crude protein compared to CFM and $\mathrm{CH}$ on dry matter basis. Crude fiber in barley was lower than clover hay. Fiber fractions contents were higher in barley green compared to CFM and $\mathrm{CH}$. Chemical composition of experimental rations were increased linearly with increasing green barley in rations except NFE and ash contents decreased in green barley (GB) rations. Results of chemical analyses of green barley in present study were higher compared with others (Intissar and Eshtayeh, 2004, and Fazaeli et al., 2011) especially crude protein was 16.90 vs $12.20 \%$. Also, NDF (63.82\%) and ADF (35.32\%) were higher compared with which obtained by Fazaeli et al., (2011) hence NDF and ADF values were $28.01 \%$ and $12.80 \%$. These results may be due to system of sprouting and nature of growing of sprouted grains, respectively.

Table (1): Chemical composition of feedstuffs and the experimental diets (\% DM basis).

\begin{tabular}{|c|c|c|c|c|c|c|c|}
\hline \multirow[b]{2}{*}{ Item } & \multicolumn{3}{|c|}{ Feedstuffs } & \multicolumn{4}{|c|}{ Experimental rations } \\
\hline & CFM & $\mathrm{CH}$ & SGB & G1 & $\mathrm{G} 2$ & G3 & G4 \\
\hline \multicolumn{8}{|c|}{ Chemical composition, \%: } \\
\hline DM & 91.65 & 90.00 & 91.80 & 91.15 & 91.29 & 91.41 & 92.33 \\
\hline $\mathrm{OM}$ & 90.44 & 91.07 & 94.65 & 90.63 & 91.44 & 92.24 & 93.84 \\
\hline Ash & 9.56 & 8.93 & 5.35 & 9.37 & 8.56 & 7.76 & 6.16 \\
\hline $\mathrm{CP}$ & 14.52 & 13.50 & 16.85 & 14.21 & 14.75 & 15.27 & 15.93 \\
\hline $\mathrm{EE}$ & 5.18 & 2.87 & 5.42 & 4.48 & 4.68 & 4.86 & 5.09 \\
\hline $\mathrm{CF}$ & 10.47 & 30.03 & 24.58 & 16.41 & 17.95 & 19.65 & 21.44 \\
\hline NFE & 60.27 & 44.67 & 47.80 & 55.53 & 54.06 & 52.46 & 51.38 \\
\hline \multicolumn{8}{|c|}{ Fiber fractions, $\%$ : } \\
\hline $\mathrm{NDF}$ & 34.75 & 40.97 & 63.82 & 36.64 & 42.09 & 47.54 & 53.34 \\
\hline $\mathrm{ADF}$ & 20.34 & 31.32 & 35.32 & 23.67 & 25.96 & 28.33 & 30.88 \\
\hline ADL & 7.07 & 8.37 & 15.69 & 7.46 & 9.12 & 10.77 & 12.49 \\
\hline Cellulose & 13.27 & 22.95 & 19.63 & 16.20 & 16.84 & 17.56 & 18.39 \\
\hline Hemi-cellulose & 14.41 & 9.65 & 28.50 & 12.96 & 16.13 & 19.21 & 22.46 \\
\hline
\end{tabular}

\section{Nutrients digestibility and nutritive values:}

Digestion coefficients and nutritive values of the experimental rations fed to growing lambs are presented in Table (2). Results indicated that no significant $(\mathrm{P}>0.05)$ differences among groups for DM, OM, CF, ADF and cellulose. On the other hand, G4 recorded higher significant values of CP, EE, NFE, NDF and hemicellulose digestibility followed by G3, G2 and G1. According to digestion coefficients and chemical composition G4 significant had highest values of TDN and DCP compared to other groups. These results agree with those of Fayed (2011), who showed that addition of sprouted barley with rice straw and Tamarix mannifera increased nutrients digestibility and this may be due to the presence of bioactive catalysts, which increases digestion and absorption of nutrients. Similarly, Morgan et al. (1992), Peer and Leeson (1985a) and Ibrahim et al. (2001) noticed and increase in nutrient digestibility by the addition of sprouted grains in ruminants ration. These may be due to sprouted grains contain grass juice factor which is a rich source of nutrients. Also, nutritional value of sprouted grain was improved due to the conversion of complex compounds into simpler and essential form and by minimizing the effect of anti-nutritional factors during germination (Chavan and Kadam, 1989). 
Table (2): Nutrients digestibility and nutritive values of the experimental rations fed to growing lambs.

\begin{tabular}{|c|c|c|c|c|c|}
\hline \multirow[t]{2}{*}{ Item } & \multicolumn{4}{|c|}{ Experimental ration } & \multirow[b]{2}{*}{$\pm \mathrm{SE}$} \\
\hline & G1 & $\mathrm{G} 2$ & G3 & G4 & \\
\hline \multicolumn{6}{|l|}{ Digestibility, $\%$} \\
\hline DM & 67.26 & 65.46 & 66.45 & 71.07 & 2.04 \\
\hline $\mathrm{OM}$ & 70.41 & 68.46 & 69.33 & 74.52 & 2.29 \\
\hline $\mathrm{CP}$ & $60.65^{c}$ & $64.87^{\mathrm{bc}}$ & $66.14^{\mathrm{b}}$ & $73.64^{\mathrm{a}}$ & 2.00 \\
\hline $\mathrm{EE}$ & $65.92^{c}$ & $71.13^{\mathrm{bc}}$ & $73.68^{\mathrm{b}}$ & $80.41^{\mathrm{a}}$ & 1.73 \\
\hline $\mathrm{CF}$ & 59.32 & 59.90 & 57.66 & 66.79 & 4.64 \\
\hline NFE & $55.02^{\mathrm{b}}$ & $54.14^{\mathrm{b}}$ & $57.60^{\mathrm{b}}$ & $65.42^{\mathrm{a}}$ & 1.67 \\
\hline $\mathrm{NDF}$ & $54.59^{\mathrm{b}}$ & $52.99^{\mathrm{b}}$ & $59.40^{\mathrm{b}}$ & $69.56^{\mathrm{a}}$ & 2.55 \\
\hline $\mathrm{ADF}$ & 55.87 & 55.91 & 59.88 & 65.51 & 2.94 \\
\hline Cellulose & 65.19 & 63.74 & 70.62 & 76.06 & 6.61 \\
\hline Hemi-cellulose & $51.18^{\mathrm{c}}$ & $58.69 b^{c}$ & $64.63^{\mathrm{ab}}$ & $75.13^{\mathrm{a}}$ & 3.46 \\
\hline \multicolumn{6}{|c|}{ Nutritive values, $\%$} \\
\hline TDN & $55.55^{\mathrm{b}}$ & $57.08^{\mathrm{b}}$ & $59.71^{\mathrm{b}}$ & $68.87^{\mathrm{a}}$ & 2.02 \\
\hline $\mathrm{DCP}$ & $8.62^{\mathrm{d}}$ & $9.57^{\mathrm{c}}$ & $10.10^{\mathrm{b}}$ & $11.73^{\mathrm{a}}$ & 0.33 \\
\hline
\end{tabular}

\section{Rumen parameters:}

Data of ruminal $\mathrm{pH}, \mathrm{NH}_{3}-\mathrm{N}$ and TVFA's concentration are presented in Table (3). Results indicated that ruminal $\mathrm{pH}$ values were significantly $(\mathrm{P}<0.05)$ higher with feeding $\mathrm{G} 1$ compared with other groups at 4 hours and mean values, while no significant differences were founded between groups before feeding.

Values of $\mathrm{NH}_{3}-\mathrm{N}$ concentration in Table (3) indicated that the lowest values was recorded at zero time and gradually increased to the maximum at 4 hours post feeding. In this respect, $\mathrm{NH}_{3}-\mathrm{N}$ concentration was found to be significantly $(\mathrm{P}<0.05)$ highest with $\mathrm{G} 3$ compared to other tested groups. Similar results were obtained by Fayed (2011). These results may be due to rations, which contained sprouted barley have high level of protein and its degradability compared to control ration.

Table (3): Effect of the experimental rations on some rumen parameters of growing lambs.

\begin{tabular}{|c|c|c|c|c|c|}
\hline \multirow[b]{2}{*}{ Item } & \multicolumn{4}{|c|}{ Experimental rations } & \multirow[b]{2}{*}{$\pm \mathrm{SE}$} \\
\hline & G1 & $\mathrm{G} 2$ & G3 & G4 & \\
\hline \multicolumn{6}{|l|}{ Rumen $\mathrm{pH}$} \\
\hline Zero time & 6.50 & 6.25 & 6.10 & 6.15 & 0.07 \\
\hline 4 hrs. post feeding & 5. $60 \mathrm{a}$ & $5.15 \mathrm{c}$ & $5.30 \mathrm{~b}$ & $5.25 b c$ & 0.04 \\
\hline Mean & $6.05 \mathrm{a}$ & $5.65 b$ & $5.70 b$ & $5.65 b$ & 0.04 \\
\hline \multicolumn{6}{|c|}{ Rumen NH3-N (mg\100 ml) } \\
\hline Zero time & 26.06 & 29.40 & 28.00 & 22.40 & 1.83 \\
\hline 4 hrs. post feeding & $30.10 \mathrm{~b}$ & $35.00 \mathrm{~b}$ & $37.80 \mathrm{a}$ & $29.40 b$ & 1.63 \\
\hline Mean & 28.35 & 32.20 & 32.90 & 25.90 & 1.28 \\
\hline \multicolumn{6}{|c|}{ Rumen TVFA's (meq $\backslash 100 \mathrm{ml}$ ) } \\
\hline Zero time & 4.30 & 5.60 & 5.60 & 5.70 & 0.39 \\
\hline 4 hrs. post feeding & 11.10 & 8.70 & 8.00 & 7.30 & 1.20 \\
\hline Mean & 7.70 & 7.15 & 6.80 & 6.50 & 0.79 \\
\hline
\end{tabular}

There were insignificant differences in TVFA's concentrations between all groups in all sampling times. Such results might be indicated that inclusion of barley green in tested rations had created similar rumen 
environment in relation to TVFA's production, which showed closer values for all dietary rations either before or after feeding. Fayed (2011) recorded same values of TVFA's, when Barki lambs were fed on sprouted barely grains on Tamarix or rice straw and mixture compared with un-treated groups. Also, Ibrahim et al. (2001) reported that TVFA's concentrations were higher for sprouted barely on rice straw and bagasse than untreated one. Concentrations of TVFA's enhanced after feeding and reach its peak after 4 hrs post feeding.

\section{Blood parameters:}

Results of Table (4) indicated that values of blood constituents were in normal range of sheep. Lambs fed G2 showed the highest significant values $(P<0.05)$ of total proteins and albumin. Control ration $(\mathrm{G} 1)$ recorded slightly higher value of urea concentration with insignificant differences with G2 and G3. No significant differences were observed among groups in globulin, creatinine ALT and AST. These results are harmony with Fayed (2011), who recorded the following values of blood biochemistry with Barki lambs fed sprouted barley: Total protein 6.13-8.19 g/dl, albumin 3.18-4.17 g/dl, globulin 3.13-4.02 g/dl, urea 35.37$67.30 \mathrm{mg} / \mathrm{dl}$ and creatinine $0.95-1.60 \mathrm{mg} / \mathrm{dl}$.

Table (4): Effect of experimental rations on blood parameters of growing lambs.

\begin{tabular}{lccccc}
\hline & \multicolumn{5}{c}{ Experimental ration } \\
\cline { 2 - 5 } Item & $\mathrm{G} 1$ & $\mathrm{G} 2$ & $\mathrm{G} 3$ & $\mathrm{G} 4$ & $\pm \mathrm{SE}$ \\
\hline Total proteins, g/dl & $6.25^{\mathrm{b}}$ & $7.20^{\mathrm{a}}$ & $6.55^{\mathrm{ab}}$ & $6.40^{\mathrm{b}}$ & 0.22 \\
Albumin, g/dl & $3.40^{\mathrm{b}}$ & $4.15^{\mathrm{a}}$ & $3.45^{\mathrm{b}}$ & $3.35^{\mathrm{b}}$ & 0.19 \\
Globulin, g/dl & 2.85 & 3.05 & 3.10 & 3.05 & 0.07 \\
Urea, mg/dl & $28.0^{\mathrm{a}}$ & $26.5^{\mathrm{ab}}$ & $27.5^{\mathrm{ab}}$ & $26.0^{\mathrm{b}}$ & 0.54 \\
CREATININE, MG/DL & 0.95 & 0.8 & 0.95 & 0.75 & 0.70 \\
ALT, IU/L & 23.0 & 23.0 & 23.5 & 22.5 & 0.74 \\
AST, IU/L & 21.0 & 22.0 & 23.5 & 22.0 & 1.30 \\
\hline B, ...MEANS IN THE SAME ROW WITH DIFFERENT SUPERSCRIPTS ARE SIGNIFICANTLY DIFFERENT $(P<0.05)$. ALT: ALANINE
\end{tabular}

AMINOTRANSFERASE, AST: ASPARTATE AMINOTRANSFERASE

\section{Growth performance:}

The results of growth performance (Table 5) showed no significant differences $(\mathrm{P}<0.05)$ among IBW of the lambs at the start of the experiment. Groups fed rations contained green barley recorded higher values of final body weight, total gain, and average daily gain being. Dry matter intake was approximately the same among groups. Feed conversion was lower with groups fed GB compared to G1. The present results of growth performance are matched with data obtained with Ata (2016) when fed hydroponic barley up to $62 \%$ from total ration for Awasi lambs.

Table (5): Effect of the experimental rations on growth performance of growing lambs.

\begin{tabular}{|c|c|c|c|c|c|}
\hline \multirow{2}{*}{ Item } & \multicolumn{4}{|c|}{ Experimental rations } & \multirow[b]{2}{*}{$\pm \mathrm{SE}$} \\
\hline & G1 & G2 & G3 & G4 & \\
\hline \multicolumn{6}{|l|}{ Live body weight: } \\
\hline Initial body weight, $\mathrm{kg}$ & 30.28 & 29.93 & 30.21 & 29.57 & 0.99 \\
\hline Final body weight, kg & $44.21^{\mathrm{b}}$ & $46.00^{\mathrm{ab}}$ & $47.93^{\mathrm{a}}$ & $47.93^{\mathrm{a}}$ & 1.43 \\
\hline Total weight gain, $\mathrm{kg}$ & $13.93^{\mathrm{b}}$ & $16.07^{\mathrm{ab}}$ & $17.72^{\mathrm{a}}$ & $18.36^{\mathrm{a}}$ & 0.89 \\
\hline Average daily gain, $\mathrm{g}$ & $154.76^{\mathrm{b}}$ & $178.56^{\mathrm{ab}}$ & $196.88^{\mathrm{a}}$ & $204.00^{\mathrm{a}}$ & 9.98 \\
\hline \multicolumn{6}{|c|}{ Feed intake, As fed, $\mathrm{Kg} / \mathrm{h} / \mathrm{d}$} \\
\hline Concentrate & 0.87 & 0.71 & 0.55 & 0.36 & ----- \\
\hline Clover hay & 0.37 & 0.30 & 0.23 & 0.16 & ----- \\
\hline Green barley & ---- & 0.95 & 1.95 & 2.91 & ----- \\
\hline \multicolumn{6}{|c|}{ Feed intake, $\mathrm{kg} / \mathrm{h} / \mathrm{d}$. on DM basis } \\
\hline Total DM intake & 1.12 & 1.14 & 1.17 & 1.16 & ----- \\
\hline \multicolumn{6}{|l|}{ Feed conversion, g/g: } \\
\hline DMI/ daily gain & 7.23 & 6.38 & 5.94 & 5.96 & ----- \\
\hline
\end{tabular}




\section{Hegab and Mahmoud}

Feeding on GB increased economic values by $31 \%, 27 \%$ and $15 \%$ with G4, G3, and G2, respectively compared to the control group (G1). These results agree with Intissar and Eshtayeh (2004), when ewes were fed on 15 and $25 \%$ from total diet of hydroponic barley. The same trend was observed with Fayed (2011), who found that addition of sprouted barley with rice straw and Tamarix mannifera increased the feed efficiency in lambs. These results are also like that reported by another researcher when Barki lambs fed commercial rations (Ghoneem, 2010 and Mahmoud, 2011).

\section{CONCLUSION}

Summing up, there were a positive effect of sprouted grains when it was used by 20 to $60 \%$ from daily dry matter intake on digestibility, rumen parameters and blood constituents and growth performance of growing lambs.

\section{ACKNOWLEDGEMENT}

The authors thank technical and laboratory staff at Faculty of Agriculture, Cairo University, Egypt for their helping in fabricating the green fodder chamber, and running the experiments, Funding for this work was provided by Misr Elkahir Association "Non-Governmental Association in Egypt" through applied research project.

\section{REFERENCES}

Al-Saadi, M.J. (2016). Productive effects and economical feasibility of substitution barley by 10 and $30 \%$ of sprouted barley in diet of Awassi male lambs. Asian Journal of Animal and Veterinary Advances, 11: 563-569. Doi:10.3923/ajava.2016.563.569

AOAC (1990). Association of Official Analytical Chemists. Official Methods of Analysis. 13 ed. Assoc. of. Anal. Chem. Washington, DC.

Ata, Mysaa (2016). Effect of hydroponic barley fodder on Awassi lambs performance. Journal of Biology, Agriculture and Healthcare, 6(8): 60-64.

Chavan, J. and S.S. Kadam (1989). Nutritional improvement of cereals by sprouting. Food Science and Nutrition, 28: 401-437. Doi:10.1080/10408398909527508

Cunniff, P. Ed., (1997). Official Methods of Analysis of AOAC International. Maryland. USA.

Doumas, B., W. Wabson and H. Biggs (1971). Albumin standards and measurements of serum with bromochresol green. Clinica Chimica Acta, 31:87.

Duncan, D. B. (1955). Multiple range and multiple F test. Biometrics, 11:1-42.

FAO (1996). Rome Deliration on World Food Security and World Food Summit Plan of Action, World Food Summit 13-17 November 1995, Rome.

FAO (2002). State of Food Insecurity in the World 2001, Rome.

Fayed, M.A. (2011). Comparative study and feed evaluation of sprouted barley grains on rice straw versus Tamarix mannifera on performance of growing Barki lambs in Sinai. Journal of American Science. 7: 954-961.

Fazaeli, H., H.A. Golmohammadi, A.A. Shoayee, N. Montajebi, and Sh. Mosharraf (2011). Performance of feedlot calves fed hydroponics fodder barley. Journal of Agricultural Science and Technology. 13, 367375.

Ghoneem, Wafaa M. A. (2010). Biological treatment of some agricultural and agroindustrial residues and their effects on performance of growing lambs. Ph.D. Thesis, Fac. of Agric., Cairo Univ. Egypt, 121 p. 
Ibrahim, A.F.H., M. El-Hosseiny and I.M. El-Sayed (2001). Effect of using sprouted barley by recycle process of agriculture residues on feeding value, rumen activity and some blood constituents of crossbred sheep. Egypt. J. Nutr. and Feeds. 4: 265-273.

Intissar F. A. and Eshtayeh (2004). A new source of fresh green feed (Hydroponic barley) for Awassi sheep. Master in environmental sciences, faculty of graduate studies, at An-Najah National University, Nablus, Palestine.

Khattak, Amal B., A. Zeb, N. Bibi, S.A. Khalil, and M.S. Khattak (2007). Influence of germination techniques on phytic acid and polyphenols content of chickpea (Cicer arietinum L.) sprouts. Food Chemistry, 104, 1074-1079. Doi: 10.1016/j.foodchem.2007.01.022.

Mahmoud, A. E. M. (2011). Freshwater reed silage as non-conventional forage in feeding lactating buffaloes and growing lambs. Ph.D. Thesis, Fac. of Agric., Cairo Univ. Egypt.

Morgan, J., R.R. Hunter and R.O. Harie (1992). Limiting factors in hydroponics barley grass production $8^{\text {th }}$ 1. Con. on soilless culture, Hunter's Rest, South Africa. P. 40.

NRC (1985). Nutrient REQUiREMENTS OF SHEEP. $6^{\mathrm{TH}}$ ED., WASHINGTON, D.C. NATIONAL ACADEMY OF SCIENCES. 45 PP.

Patton, F.G. and S.R. Grouch (1977). Colorimetric determination of urea. Anal Chemistry, 49, 468.

Peer, D.J. and S. Leeson (1985a). Feeding value of hydroponics sprouted barley for poultry and bigs. Animal Feed Science and Technology, 13: 183-190

Peer, D.J. and S. Leeson (1985b). Nutrient content of hydroponically sprouted barley. Animal Feed Science and Technology, 13: 191-202.

Preston, T.A. (1995). Tropical Animal Feeding - A Manual for Research Worker. FAO Animal Production and Health Paper 126. Rome. http://www.fao.org/ag/aga/agap/frg/AHPP126/ahpp126.htm

SAS (2001). User's guide. Statistic. Ver.8.02, SAS Institute Inc., Cary, NC, USA

Sneath, R. and F. McIntosh (2003). Review of hydroponic fodder production for beef cattle. Department of Primary Industries: Queensland Australia 84. McKeehen, pp: 54.

Tietz, N.W. (1986). Text Book of Clinical Chemistry. W. B. Saunders, Philadelphia, 1271.

Tietz, N.W. (1990). Clinical Guide to Laboratory Tests $2^{\text {nd }}$ Ed. Philadelphia.

Van Soest, P. J., J.B. Robertson and B.A. Lewis (1991). Methods for dietary fiber, neutral detergent fiber, and nonstarch polysaccharides in relation to animal nutrition. J. Dairy Sci. 74: 3583-3597. Doi.org/10.3168/jds.S0022-0302(91)78551-2

Vendramini T.H.A., C.S. Takiya and T.H. Silva (2016). Effects of a blend of essential oils, chitosan or monensin on nutrient intake and digestibility of lactating dairy cows. Animal Feed Science and Technology. 214:12-21. DOI: http://dx.doi.org/10.1016/j.anifeedsci.2016.01.015

Young, D. S. (1997). Effects of Preanalytical Variables on Clinical Laboratory Tests. 2nd Edn., AACC Press, Washington, DC., USA., ISBN-13: 9780915274888 , Pages: 1285. 
تأثير الأعلاف الخضر اء المستنبته علي أداء الحملان النامية

خالا خليل حجاب1 و عادل عيد محمد محمود2

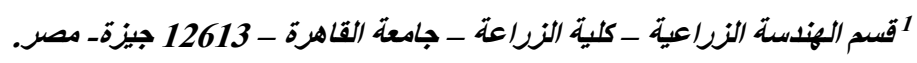

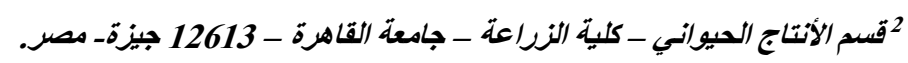

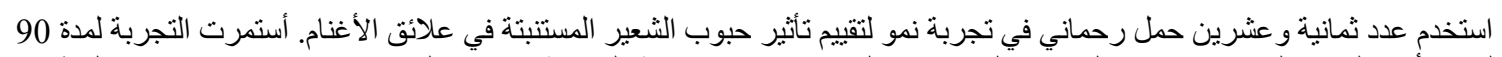

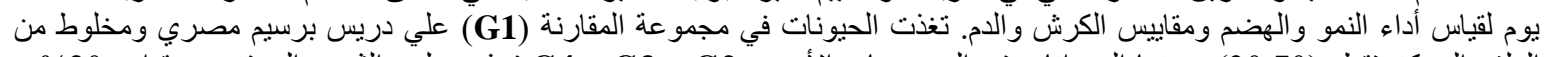

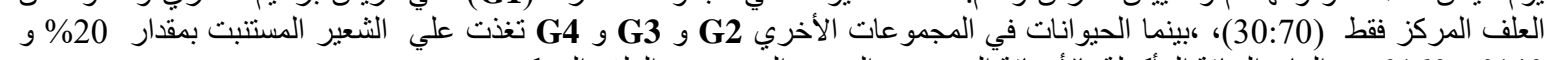

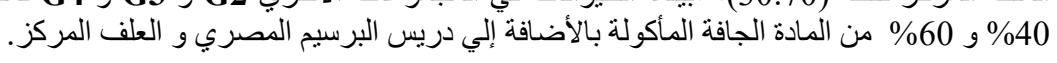

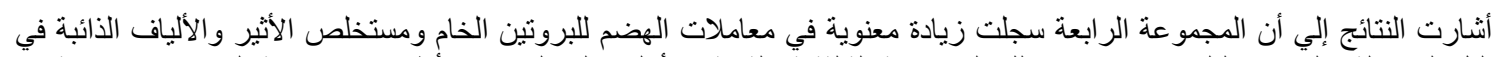

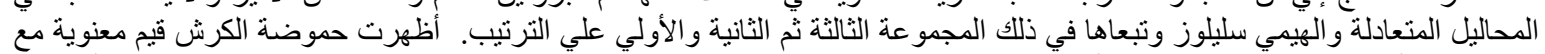

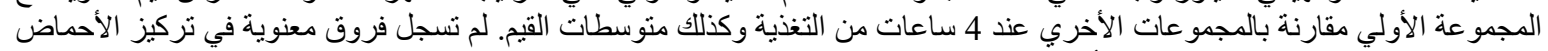

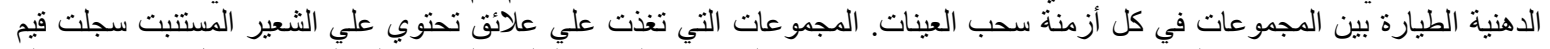

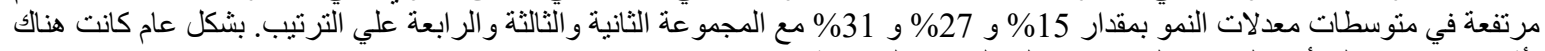
تأثير ات إيجابيه علي أداء الحملان الني تغذت علي الحبوب المستنبتة. 